\title{
Lack of Correlation between Methicillin Resistance and Susceptibility to Lysostaphin in Staphylococcus aureus
}

\author{
By I. CHOPRA AND R. W. LACEY \\ Department of Bacteriology, The Medical School, University of Bristol, Bristol BS8 ITD
}

(Received 3I January 1974)

INTRODUCTION

Naturally occurring methicillin-resistant staphylococci consist of populations of bacteria with varying levels of resistance to the drug (for example, see Dyke, 1969). Sabbath, Leaf, Gerstein \& Finland (1970) and Sabath \& Wallace (197I) have shown that organisms uniformly resistant to methicillin, selected from such heterogeneous populations with cloxacillin, are also relatively more resistant to lysis by lysostaphin than cultures of predominantly methicillin-sensitive organisms. Although decreased susceptibility to lysis in these strains is probably the result of membrane changes (Sabath \& Wallace, 197I), the relationship of such alterations to the mechanism of methicillin resistance is unclear. Since the strains were probably non-isogenic (i.e. differed in properties other than variation in methicillin resistance) it is possible that the observed resistance to lysostaphin was unrelated to methicillin resistance. However, to establish whether or not a correlation does exist, we have compared the rates of lysis by lysostaphin of pairs of strains differing only in the possession of the gene(s) for methicillin resistance. Acquisition of methicillin resistance did not affect susceptibility to lysis by lysostaphin.

\section{METHODS}

Methicillin resistance was transduced from strain DU4916 (Dornbusch, Hallander \& Löfquist, 1969) to two recipients: strain II 64 met-s, a methicillin-sensitive derivative of strain 1164 (Lacey, 1972), and strain 649MR, a strain that harbours six plasmids (Lacey \& Chopra, 1974). A transducing lysate was prepared by propagation of typing phage 88 in three successive cycles, followed by filtration three times through a Millipore filter of $0.45 \mathrm{~nm}$ pore size. Transduction was by the method of Lacey (1972) with a phage-to-cell ratio of $0 \cdot \mathrm{I}$. Transductants were selected on nutrient agar containing $25 \mu \mathrm{g}$ methicillin/ml after incubation at $30^{\circ} \mathrm{C}$ for $72 \mathrm{~h}$. They resembled the parent strains in phenotypic properties, including phage typing pattern, except in the acquisition of heterogeneous resistance to methicillin. Thus, strains I I 64 met-s and I I 64 met-r, and 649MR and 649MR met-r, were considered isogenic pairs except for the variation in methicillin resistance.

Estimation of the susceptibility of strains to lysostaphin was performed as follows. Midlogarithmic phase cultures (at cell densities equivalent to $0.33 \mathrm{mg}$ dry wt cells $/ \mathrm{ml}$ ) grown either at 30 or $37^{\circ} \mathrm{C}$ in nutrient broth, were harvested by centrifugation (15,000 $\mathrm{g}, 20 \mathrm{~min}$, $4^{\circ} \mathrm{C}$ ) and washed twice in cold tris-saline buffer ( $50 \mathrm{~mm}$-tris, $100 \mathrm{mM}-\mathrm{NaCl}, \mathrm{pH} 7 \cdot 5$ ). Cultures were resuspended in the above buffer to give an extinction at $675 \mathrm{~nm}$ of 0.40 , and equilibrated to either 30 or $37^{\circ} \mathrm{C}$ before the addition of lysostaphin (I $\mu \mathrm{g} / \mathrm{ml}$ final). Incubation was continued at the respective temperature with gentle swirling, and samples were removed at intervals for estimation of extinction at $675 \mathrm{~nm}$. From these data, a series of curves was constructed from which the rate of $50 \%$ lysis could be computed. 
Table I. The rate of lysis of methicillin-sensitive and resistant Staphylococci by lysostaphin

\begin{tabular}{|c|c|c|c|}
\hline \multirow[b]{3}{*}{ Strain } & \multirow{2}{*}{\multicolumn{2}{|c|}{$\overbrace{\text { Growth and lysis at }\left({ }^{\circ} \mathrm{C}\right)}^{\begin{array}{c}\text { Period (min) required } \\
\text { for } 50 \% \text { reduction in } E_{675}\end{array}}$}} & \multirow{3}{*}{$\begin{array}{c}\text { Minimal } \\
\text { inhibitory } \\
\text { concentration } \dagger \\
(\mu \mathrm{g} \text { methicillin } / \mathrm{ml})\end{array}$} \\
\hline & & & \\
\hline & 30 & 37 & \\
\hline $\begin{array}{l}\text { 649MR met-r } \\
\text { 649MR }\end{array}$ & $\begin{array}{l}15 \cdot 2 \\
16 \cdot 4\end{array}$ & $\begin{array}{l}6 \cdot 4 \\
8 \cdot 1\end{array}$ & $\begin{array}{r}>1000 \\
2\end{array}$ \\
\hline $\begin{array}{l}\text { I I I } 64 \text { met }-r \\
\text { I I I } 64 \text { met }-s\end{array}$ & $\begin{array}{l}22 \cdot 0 \\
21 \cdot 0\end{array}$ & $\begin{array}{l}17 \cdot 2 \\
14 \cdot 8\end{array}$ & $\begin{array}{r}1000 \\
2\end{array}$ \\
\hline
\end{tabular}

* Values quoted are the means of at least two independent experiments.

$\dagger$ To methicillin at $30^{\circ} \mathrm{C}$; performed by the method of Lacey (1972).

\section{RESULTS AND DISCUSSION}

Methicillin resistance was only exhibited by about one cell in $10^{5}$ when cultures were grown in nutrient broth at $37^{\circ} \mathrm{C}$. Thus, even if methicillin resistance was correlated to the rate of lysis by lysostaphin, the rates of lysis of methicillin-resistant or sensitive strains grown at $37^{\circ} \mathrm{C}$ in nutrient broth should be similar. Indeed, the rate of lysis of methicillinresistant strains grown and lysed at $37^{\circ} \mathrm{C}$ was very similar to that of their methicillinsensitive counterparts (Table I). It is notable that the III64 strains lysed at markedly lower rates than the 649 strains.

However, the rate of lysis of methicillin-resistant strains grown and lysed at $30{ }^{\circ} \mathrm{C}$ (at this temperature every cell shows resistance to methicillin) was virtually identical to that of their methicillin-sensitive counterparts (Table I). As at $37^{\circ} \mathrm{C}$, the I I 164 strains were lysed at lower rates than the 649 strains. It seems, therefore, that methicillin resistance is unrelated to resistance to lysis by lysostaphin.

This work was supported by grants from the Medical Research Council to Professor M. H. Richmond.

\section{REFERENCES}

Dornbusch, K., Hallander, H. O. \& LöfQuist, F. (1969). Extrachromosomal control of methicillin resistance and toxin production in Staphylococcus aureus. Journal of Bacteriology 98, 351-358.

DyKe, K. G. H. (1969). Penicillinase production and intrinsic resistance to penicillins in methicillin-resistant cultures of Staphylococcus aureus. Journal of Medical Microbiology 2, 26I-278.

LACEY, R. W. (1972). Genetic control in methicillin-resistant strains of Staphylococcus aureus. Journal of Medical Microbiology 5, 497-508.

LACEY, R. W. \& ChOpRA, I. (1974). Genetic studies of a multiresistant strain of Staphylococcus aureus. Journal of Medical Microbiology (in the Press).

Sabath, L. D., Leaf, C. D., Gerstein, D. A. \& Finland, M. (1970). Altered cell walls of Staphylococcus aureus resistant to methicillin. Nature, London 225, 1074.

Sabath, L. D. \& Wallace, S. J. (I97I). Factors influencing methicillin resistance in staphylococci. Annals of the New York Academy of Sciences 182, 258-266. 